\title{
ZAKI NAGUIB MAHMOUD'S THOUGHT ON IDEAL POLITICS (From Social-Criticism to Liberating-Nationalism)
}

\author{
Supriyanto \\ Universitas Islam Negeri Prof. K.H. Saifuddin Zuhri Purwokerto \\ Banyumas, Central Java, Indonesia \\ E-mail:supriyanto@iainpurwokerto.ac.id \\ Doromae Hayeehasa \\ Jamiah Islam Syeikh Daud Al-Fathoni \\ Yala, Thailand \\ E-mail:dw.familygroup@gmail.com
}

\begin{tabular}{c|c|c}
\hline Received: & Revised: & Approved: \\
$04 / 06 / 2021$ & $09 / 11 / 2021$ & $12 / 12 / 2021$ \\
\hline
\end{tabular}

DOI : 10.32332/akademika.v26i2.3326

\begin{abstract}
Political dynamics in Muslim countries experienced turbulence after the collapse of the Ottoman Empire. In the midst of uncertainty about model of Islamic politics in Muslim countries, sometimes they even deny each other, this has prompted the birth of an offer of Islamic political thought by the great Muslim thinker, Zaki Naguib Mahmoud. This study aims to reveal the ideal political model of Islam in the context of the contemporary nation state. The researcher examines Zaki's thinking as a representation of contemporary Muslim scholar who have a long scientific anchor in the Muslim tradition. This research is qualitative research with a discourse analysis method. As a result, Zaki offers a political concept that is not only oriented to the struggle for power, but a political concept that liberates, prospers, and always tries to build a better life order. Zaky is here to oppose the tyranny of power and the hegemony of the majority over the minority. For the Arabs, the realization of such a political vision is not impossible, considering that they have a noble heritage in the form of a spirit of nationalism rooted in the era of their predecessors. It is this spirit that should be able to create a political order capable of liberating the entire Arab nation from backwardness, decline, and moral degradation.
\end{abstract}

Keywords: Politic, nationalism, liberation, tyranny, and power

\section{A. Introduction}

After the collapse of the Ottoman government (1924) and the development of the political trend to establish a nation-state, the situation in the Islamic world was in political uncertainty and confusion. ${ }^{1}$ In this situation, several political thoughts emerged among Islamic thinkers that illustrate how the direction of Islamic politics has lost its direction, resulting in highly varied patterns of thinking that mutually reject one

\footnotetext{
${ }^{1}$ Yassamine Mather, 'The Fall of the Ottoman Empire and Current Conflict in the Middle East', Critique 42, no. 3 (3 July 2014): 471-75, https://doi.org/10.1080/03017605.2014.972151.
} 
another. $^{2}$

The pattern of secular-political thought was displayed by Ali Abdurraziq with his controversial monumental work, Al-Islām wa Ușül al-Hukm. This book provoked a strong reaction from some Muslim communities and demanded Ali Abdurraziq be brought to justice because Abdurraziq not only criticized the legitimacy of the caliphate system but also questioned the basics of power in Islam as a whole. According to him, Islam does not have a certain standard political concept. The caliphate, like any other "standard-Islamic" political structure, lacks a firm foundation in both the Qur'an and alSunnah. ${ }^{3}$

Contrary to Abdurraziq's secular thinking, ${ }^{4}$ another group of thinkers emerged who carried the concept of the caliphate in one Muslim leadership. One of them was Taqiyyudin an-Nabhani, a figure who carried the concept of Dawlah Khilafah Islamiyyah, a concept that requires the establishment of an Islamic government system throughout the world. ${ }^{5}$ An-Nabhany's idea was later developed in a "political" movement by Hizb at-Tahrir al-Islamī, including by Hizbut Tahrir Indonesia (HTI). ${ }^{6}$

Different Islamic political thoughts were also conveyed by Abd al-Razzaq alSanhuri. Although he was different from the concept of the caliphate, al-Sanhuri did not really demand that the Islamic government be implemented in the form of a government system. The main substance of Islamic government is Islamic values, not the system of government and power. The idea of as-Sanhuri in Fiqh al-Khiläfah wa Tațawwuruhā is often referred to as a new format of the Islamic caliphate (Khilafah Islamiyyah). ${ }^{7}$

The various perspectives and discourses on Islamic politics is a portrait that this issue is ijtihadi and discursive. Therefore, there is no standard and permanent political concept and system to be associated with what is referred to as "Islamic politics". In fact, the concept and system of the Islamic caliphate which is often claimed as a political system inherited from the Prophet (Islam) cannot attract the thoughts and political tendencies of the majority of Muslims. The concept and system (Khilafah) are often interpreted as a political choice whose effectiveness is highly dependent on a particular place and time, not a universal, standard, and permanent political system.

${ }^{2}$ Zhongmin Liu and Meng Shu, 'Nationalist Thoughts and Islam in the Late Ottoman Empire', Asian Journal of Middle Eastern and Islamic Studies 11, no. 2 (1 June 2017): 14-26, https://doi.org/10.1080/25765949.2017.12023298.

${ }^{3}$ Al-Rāziq Alī Abd, Al-Islām Wa Ușūl al-Hukm, trans. Mamduh Haqq (Beirut, 1966), 40-42.

4 Badarussyamsi Badarussyamsi, 'Pemikiran Ali Abdurraziq Tentang Hubungan Islam Dan Negara', TAJDID: Jurnal Ilmu Ushuluddin 14, no. 2 (2 November 2015): 325, https://doi.org/10.30631/tjd.v14i2.5; Jumni Nelli, 'Pemikiran Politik Ali Abd Al-Raziq', An-Nida' 39, no. 1 (5 February 2014): 76, https://doi.org/10.24014/an-nida.v39i1.866; Asep Ramdan Hidayat, 'Islam dan Negara Pemikiran Ali Abd. Ar-Raziq', MIMBAR: Jurnal Sosial dan Pembangunan 19, no. 2 (8 June 2003): 159, https://doi.org/10.29313/mimbar.v19i2.100; Burhanuddin Yusuf, 'Ali Abdul Raziq Kajian Teologis Atas Pemikirannya', Aqidah-Ta: Jurnal Ilmu Aqidah 3, no. 1 (2017): 1, https://doi.org/10.24252/aqidahta.v3i1.3274.

${ }^{5}$ Taqiyudin an-Nabhany, Pembentukan Partai Politik Islam, trans. Zakaria Labib, 2nd ed. (Jakarta: Penerbit HTI Press, 2007), 10.

${ }^{6}$ Syamsul Rijal, 'Indoctrinating Muslim Youths: Seeking Certainty Through An-Nabhanism', AlJami'ah: Journal of Islamic Studies 49, no. 2 (24 December 2011): 253-54, https://doi.org/10.14421/ajis.2011.492.253-280; Mohamed Nawab Mohamed Osman, 'Hizbut Tahrir Malaysia: The Emergence of a New Transnational Islamist Movement in Malaysia', Al-Jami'ah: Journal of Islamic Studies 47, no. 1 (26 June 2009): 91-110, https://doi.org/10.14421/ajis.2009.471.91-110; M. Nurdin Zuhdi, 'Kritik Terhadap Penafsiran Al-Qur'an Hizbut Tahrir Indonesia', Akademika: Jurnal Pemikiran Islam (Online) 18, no. 2 (22 October 2013): 209-34.

${ }^{7}$ Abd ar-Razzāq As-Sanhuri, Fiqh Al-Khilāfah Wa Tațawwuruhā (Kairo: al-Haiah al-'Ammah lil Kitab, 1993). 
Among the Muslim reformers who also had interesting political ideas was Zaki Naguib Mahmud (1902-1993). He lived in Egypt with dynamic political upheavals that made him have a political perspective that is worthy of study. On the one hand, Egypt is part of an Arab region with a very strong Islamic tradition, but on the other hand, the political system in Egypt displays a dynamic movement that does not always prioritize the formalization of Islam in the management of the state and power. ${ }^{8}$ The idea of Egyptian nationalism in particular, and Arabic, in general, was very influential on the character of Zaki's thinking. ${ }^{9}$ However, the breadth of his thinking and the process of academic development involving the two poles of the world (West-East) made Zaki's political ideas different from the nationalist ideas of other Muslim thinkers, including his political ideas in general. ${ }^{10}$ Authors using qualitative approach to conduct this research. A discourse method was employed to analysis the data.

\section{B. Paradigms and Typology of Islamic Political Thought}

There are three major paradigms regarding Islamic politics and the history of its development, namely:

1. Traditional Paradigm

The traditional paradigm is often interpreted as an effort to institutionalize religious practices that are believed in the entire order of life. It is called traditional if someone has a strong commitment to religious rules in all his behavior in life. ${ }^{11} \mathrm{~A}$ "traditional Muslim" is always bound by the traditions handed down by the early generations of Islam which are believed to be the original and genuine practice of Islamic teachings. This is where the traditional paradigm is often confronted with the Western world which tends to ignore tradition. ${ }^{12}$ From a religious point of view, the life of the Egyptian people belongs to the traditional group. ${ }^{13}$

In the political realm, the traditional view of Islam can be seen from the effort to base the system of state management and power on Islamic norms. ${ }^{14}$ Therefore, political systems such as caliphate, mamlakah, imamat, or anything that is based on Islamic norms and has been practiced by early generations of Muslims must be accepted as a form of implementation of Islamic law in the political sphere. ${ }^{15}$ The political thoughts of classical Islamic scholars such as al-Ghazali, al-Mawardi, and al-Taftazani can be

\footnotetext{
${ }^{8}$ Chihab El Khachab, 'A Brief History of the Future of Culture in Egypt', Journal of the African Literature Association 15, no. 3 (2 September 2021): https://doi.org/10.1080/21674736.2021.1935065; Menachem Klein, 'Egypt's Revolutionary Publishing Culture, 1952-62', Middle Eastern Studies 39, no. 2 (1 April 2003): 149-50, https://doi.org/10.1080/714004504; Gabriel R. Warburg, 'Islam and Politics in Egypt: 1952-80', Middle Eastern Studies 18, no. 2 (1 April 1982): 131-57, https://doi.org/10.1080/00263208208700502; Ioana E. Matesan, 'The Impact of the Arab Spring on Islamist Strategies', Journal of Strategic Security 5, no. 2 (2012): 27-28, http://dx.doi.org/10.5038/1944-0472.5.2.2.

${ }^{9}$ Efraim Karsh and Inari Karsh, 'Reflections on Arab Nationalism', Middle Eastern Studies 32, no. 4 (1 October 1996): 367-92, https://doi.org/10.1080/00263209608701135.

10 Muhamad Ali, 'Nationalism and Islam: Perspective of Egyptian and Syrian Muslim Intellectuals', Indonesian Journal of Islam and Muslim Societies 4, no. 1 (1 June 2014): 51-79, https://doi.org/10.18326/ijims.v4i1.51-79.

${ }^{11}$ Sayyed Hossein Nasr, Traditional Islam in Modem World (London: Oxford University, 1983), 13.

${ }^{12}$ Munawwir Syadzali, Islam Dan Tata Negara (Jakarta: UI Press, 1990), 115.

${ }^{13}$ Ali Munhanif and M. Dahlan, 'Lineages of Islamic Extremism in Egypt: Ikhwan al-Muslimun, State Violence and the Origins of Radical Politics', Al-Jami'ah: Journal of Islamic Studies 56, no. 2 (8 September 2018): 425, https://doi.org/10.14421/ajis.2018.562.421-460.

${ }^{14}$ Syadzali, Islam Dan Tata Negara, 15.

${ }^{15}$ Nasr, Traditional Islam in Modem World, 17.
} 
grouped in the traditional paradigm. Meanwhile, in the modern era, the traditional Islamic political paradigm can be referred to as the thoughts of Rasyid Rida (18651935) and Abdul Kalam Azad (1888-1958) ${ }^{16}$.

\section{Modernist Paradigm}

The modernist paradigm is the opposite of the traditionalist paradigm. This paradigm by Qodir and Saeed is called a progressive paradigm. ${ }^{17}$ In the modernist paradigm, the root of the backwardness of Islamic civilization is considered to come from the stagnation of thought and the stagnation of scholars in understanding Islam, especially in responding to the dynamics of modern life. ${ }^{18}$ There is no other way to restore Muslims as "khayr ummah" who can take an important role in the modern world order, other than reopening the faucet of thought (ijtihad) that has been blocked for a long time. Innovation and renewal are the main projects that must be campaigned in order to catch up with the West.

The idea of innovation and renewal (al-tajdìd wa al-ișlāh) in its development is transformed into a political thought movement which typologically can be divided into: 1) rationalization movement, 2) secularization movement, and 3) reconstruction movement. The first typology was represented by Muhammad Abduh (1849-1905), the second was represented by Ali Abd al-Raziq (1888-1966), ${ }^{19}$ while the third typology was represented by Muhammad Iqbal (1875-1938). ${ }^{20}$

\section{Fundamentalist Paradigm}

The fundamentalist paradigm has several similarities and differences at the same time as the traditionalist and modernist paradigms. In making Islamic teachings as the basis for state administration, the fundamentalist paradigm can be reconciled with the traditionalist paradigm. The difference is that the fundamentalist paradigm tries to make Islamic teachings not only as the spirit and norms of state administration but also as a system of state administration (Khilafah). ${ }^{21}$ Meanwhile, Traditionalist groups, on the other hand, place a greater emphasis on qualities of spirit and traditions rather than governmental structures and governance.

The similarity with the modernist paradigm is that they both emerged in the modern era and fought the same adversary, the secular-rational Western world. The difference is that fundamentalist groups try to deal with Western hegemony by trying to draw the lives of Muslims back to the early days of Islam and "duplicate" various behaviors that are believed to be the prototype of true Islam as exemplified by the early Muslim community (al-Salaf al-Salih). On the other hand, modernists said that instead of returning to the early days of Islam and avoiding contact with the Western world, the modernists are eager to copy Westerners' working and thinking methods, which are

${ }^{16}$ Asghar Ali Engineer, 'Theological Creativity of Abul Kalam Azad', Indian Literature 31, no. 4 (126) (1988): 17-29; Qazi Mohd. Jamshed, 'Ideological Influences on Abul Kalam Azad', Proceedings of the Indian History Congress 71 (2010): 662-76.

${ }^{17}$ Zuly Qodir et al., 'A Progressive Islamic Movement and Its Response to the Issues of the Ummah', Indonesian Journal of Islam and Muslim Societies 10, no. 2 (21 December 2020): 323-52, https://doi.org/10.18326/ijims.v10i2.323-352; Abdullah Saeed, Interpreting the Qur'ān: Towards a Contemporary Approach (Abingdon [England] ; New York: Routledge, 2006), 3.

${ }^{18}$ Nasr, Traditional Islam in Modem World.

${ }^{19}$ Syadzali, Islam Dan Tata Negara, 139.

${ }^{20}$ Ahmad Syafii Maarif, 'Muhammad Iqbal Dan Suara Kemanusiaan Dari Timur', in Rekonstruksi Pemikiran Agama Dalam Islam, trans. Ali Audah (Yogyakarta: Jalasutra, 2008), xi.

${ }^{21}$ Masoud Kazemzadeh, 'Teaching the Politics of Islamic Fundamentalism', PS: Political Science and Politics 31, no. 1 (1998): 52-54, https://doi.org/10.2307/420434. 
considered as not opposing Islamic principles. According to them (the modernist group), many behaviors of Western people are actually in line with Islamic teachings, and, not infrequently, the behavior of Muslims is actually not in line with the teachings of their religion. ${ }^{22}$ In fact, the fundamentalism paradigm established radical extremist groups. $^{23}$

Several Islamic political thinkers who could be categorized as bearers of the fundamentalist paradigm were Abul A'la Maududi (1903-1979) and Sayyid Qutub (1906-1966). ${ }^{24}$ These two figures were known as ideologues who often spread political ideas in which Muslims must always rely on their power-political activities to religious authoritative sources (al-Qur'an and al-Sunnah).

In general, the political thinking of fundamentalist groups is based on three assumptions. First, Islam is a complete religion that is complete with instructions to regulate all aspects of human life including the political field (Islamic political system). Second, Sovereignty is in the hands of God, while humans are only the executor of that sovereignty as God's caliph on earth, and reject the notion of popular sovereignty. Third, the Islamic political system is a universal system and does not recognize geographical, linguistic, and national boundaries and ties. ${ }^{25}$ From these three assumptions, political aspirations developed to establish an Islamic political system under one leadership, namely the Islamic caliphate, an idea that does not seem to have the support of the majority of Muslims today.

In addition to the three paradigms above, Islamic political discourse also creates at least four patterns of thought. ${ }^{26}$ The first is a philosophical style. Islamic political thought with a philosophical style tries to offer an ideal framework of an Islamic government which is characterized by the emergence of the concept of an ideal state (almadinah al-fädilah). According to al-Farabi, the ideal state is a state concept that reflects the harmony between the government and the people in a joint effort to build superior (main) individuals and communities in order to achieve happiness in life. ${ }^{27}$ From the philosophical perspective, this style of political thought is very closely related to the figures of al-Farabi and Ibn Sina. However, if it is traced genealogically, the idea of an ideal state will arrive at the thoughts of Greek philosophers such as Aristotle and Plato. ${ }^{28}$

The second is the legal style (formal legal), which is a style of political thought

${ }^{22}$ Read more. Muslim Contributions to World Civilization (International Institute of Islamic Thought, 2005), https://doi.org/10.2307/j.ctvk8w275.

${ }^{23}$ Irham Irham and Zakaria Husin Lubis, 'The Dynamics of Contemporary Islamic Thinking and the Roleof Education: Islamic Fundamentalism, Opponents, and Hybrid Thought', Al-Tahrir: Jurnal Pemikiran Islam 21, no. 1 (18 May 2021): 108.

${ }^{24}$ Ilman Nafia and Septi Gumiandari, 'The Root of Islamic Fundamentalism in The Political Thoughts of Al-Maududi and Sayyid Qutb: A Historical Study', Jurnal Tamaddun : Jurnal Sejarah Dan Kebudayaan Islam 7, no. 2 (1 December 2019): 258, https://doi.org/10.24235/tamaddun.v7i2.5497.

${ }_{25}$ Syadzali, Islam Dan Tata Negara, 15; Imam Mustofa et al., 'Reading Types of Islamic Fundamentalism in Lampung Province (A Study on Doctrine and Movement of Islamism at Lampung University)', QIJIS (Qudus International Journal of Islamic Studies) 7, no. 2 (30 December 2019): 269, https://doi.org/10.21043/qijis.v7i2.5719.

${ }^{26}$ Imam Sukardi, Pemikiran Politik Al-Farabi (Diskursus Kepemimpinan Negara), Disertasi (Jakarta: SPs UIN Syarif Hidayatullah, 2008).

27 Al- Farābī, Arā' Ahl Madīnah al-Faḍilah (Beirut: Dar wa Maktabah al-Hilal, 1995), 116; Sirajuddin Syamsuddin, 'Pemikiran Politik: Aspek Yang Terlupakan Dalam Sistem Pemikiran Islam', in Refleksi Pembaharuan Pemikiran Islam (Jakarta: LSAF, 1989), 247.

${ }^{28}$ Ubaid Umar, Al-Syaikh al-Ra'īs Ibn Sinā (Riyadh: Dār al-Syawwāf li al-Ṭibā'ah wa al-Nasyr, 1989), 48. 
that proposes theories that focus on legitimacy theory. ${ }^{29}$ The point of view used is Islamic law, so the validity of the object of thought is determined from the point of view of fiqh. Among its initiators were al-Mawardi (d. 1058 AD), Abu Ya'la ibn Farra' (d. 1056 AD), Ibn Taimiyah (d. 1328 AD), and others.

The focus of attention from this style of thinking is on the theory of government (Khilafah) which has historically been with a very formal and rigid emphasis. According to them, the caliphate is sometimes identified with Imamah. This Khilafah or Imamah is a religious institution as well as a political institution that must be preserved. They put forward arguments based on the Quran by elaborating the texts of the AlQur'an on deliberation and introducing the concept of ahl al-hall wa al-'aqd in order to legitimize the power of the caliph.

The third is the style of bureaucracy. It is a pattern of thought that describes the logical consequences of the expansion of Islamic power, especially after the khulafaur rasyidin period such as both in the Umayyad dynasty and the Abbasid dynasty that they needed a lot of administrative staff to regulate the government mechanism. The nation's lack of skill in this field caused many Persians who had converted to Islam to be asked to occupy these government positions.

The fourth is ethical patterns, namely a pattern pioneered by al-Ghazali by saying that the sultan (ruler) has a position as the shadow of God on earth (zillulläh fi al-'Ard ), therefore all people must submit and obey. Even in Kimyā'i $S a^{\prime} \bar{a} \bar{a} t$, al-Ghazali explicitly interpreted the term "ulil amri" contained in the QS. Annisa': 58 as Amir, the highest position of power during the Seljuk Dynasty. ${ }^{30}$

In general, the map of Muslims related to the relationship between religion and the state, or Islam and politics is that they are at least divided into 3 major groups; First, Fundamental Islamists, namely those who want a formal Islamic form of government, whether it is an Islamic State or an Islamic caliphate and refer to the basic sources of Islam (al-marja' al-asās $\bar{\imath}){ }^{31}$ Second, moderate Islamists, namely those who try to combine religious teachings with developing concepts, such as democracy and others; Third, secular Islamists, namely those who want religion and politics to be separated. Under these three groups, Muslims with their differences develop in each group. ${ }^{32}$

\section{Zaki Naquib Mahmud and His Political Ideas}

1. Biography of Zaki Naguib Mahmud

Zaki Naguib Mahmoud (1902-1993) was an Egyptian philosopher and humanist who was born in the village of Mayyit Al-Khauli, Dimyath Province, Egypt on February 1, 1902. He obtained a Doctorate degree in philosophy from the University of London in 1947. In 1965, he became a lecturer at the Department of Philosophy, Faculty of Humanities, Cairo University. Then, in 1965 he became Professor of Philosophy at the University of Kuwait, and had been a guest lecturer at Columbia University in South Carolina (1953), and Bullman University in Washington DC in 1954.

One of the scholars of Zaki's thought, Imam Abdul Fattah, said that in order to

${ }^{29}$ Charles C. Goetsch, 'The Future of Legal Formalism', The American Journal of Legal History 24, no. 3 (1980): 221-56, https://doi.org/10.2307/844666.

${ }^{30}$ Syamsuddin, 'Pemikiran Politik', 247.

${ }^{31}$ Knut S. Vikør, 'Islamic Law in the Modern World: States, Laws, and Constitutions', in Islamic Studies in the Twenty-First Century, ed. Léon Buskens and Annemarie van Sandwijk, Transformations and Continuities (Amsterdam University Press, 2016), 220, https://doi.org/10.2307/j.ctt1zxsk97.13.

32 Supriyanto Abdi, 'Understanding Religion-State Relations in Muslim Societies: Beyond Essentialist and Secular-Liberal Narratives', Indonesian Journal of Interdisciplinary Islamic Studies (IJIIS) 1, no. 1 (8 February 2018): 27-48, https://doi.org/10.20885/ijiis.vol1.iss1.art2. 
understand Zaki's thinking comprehensively, one must be able to see the three phases of thought development that he experienced:

a. Ordinary Religious Phase

This phase occurred before Zaki conducted his studies in Europe (London). In this phase, he criticized a lot of social life in Egypt which was considered not in line with the spirit of enlightenment as called for by classical and modern philosophers. Several of his books written with Ahmad Amin, such as Qișsah alFalsafah al-Yunāniyah, Qișșah al-Falsafah al-Hadith, and Qișsah al-Adab fi al'Alam have narrated Zaki's anxiety about the social life of Egyptian society at that time.

b. Pure Intellect Phase

The second phase occurred when Zaki returned from Europe and lasted until the 60s. At this stage, Zaki really showed his influence on European thought and civilization. He called for the Arab world to make Europe a beacon of civilization that could be imitated. In Boulotta's typology, Zaki's model of thought was categorized as a transformative model, in which Zaki wanted Arabs to be completely free from their past traditions, and took the traditions that developed in Europe instead.

c. Enlightened Religious Phase.

This third phase can be called the "maturity" phase of Zaki's thinking. In this phase, Zaki was still able to be present as a figure who was critical of Arab culture and thought, but not "Europe-centric". If in the previous phase Europe became the ideal of how Arab culture and thought should be directed, then in this phase Zaki actually called for efforts to rebuild Arab culture and thought to be carried out with a renewal project that does not leave classical Islamic culture. ${ }^{33}$

Understanding Zaki's thoughts without seeing the three phases of his thought development will result in reductive conclusions and tend to be rushed. This also includes in understanding Zaki's views on politics that was also greatly influenced by the three phases. ${ }^{34}$

\section{Socio-Cultural Criticism of Zaki Naguib Mahmoud}

In Egypt's socio-political discourse, Zaki was known as one of the thinkers who was very critical of social issues that developed in Egypt and the Arab World in general. With the big umbrella of "Nationalism", Zaki often criticized the social conditions that Egypt thought were far from ideal. In a metaphorical expression, Zaki said that Egyptian society was like the owner of a house that had luxurious furniture but was not able to function optimally. Damage that occurs to the furniture or the negligence of the guards, is the cause of the nonoptimal function of the furniture. ${ }^{35}$

Zaki's critique of the social conditions of Egyptian society was the most dominant

${ }^{33}$ Compare with Jabiri's thought. Muhamad Rofiq, 'Arab Political Reasoning: Muhammad Abid Al-Jabiri's Contribution for Understanding Crisis of Politics in the Arab World', Indonesian Journal of Islam and Muslim Societies 7, no. 1 (1 June 2017): 65, https://doi.org/10.18326/ijims.v7i1.55-76; Muhammad Iqbal Juliansyahzen, 'Rekonstruksi Nalar Arab Kontemporer Muhammad 'Abed Al-Jabiri', Indonesian Journal of Islamic Law 1, no. 2 (26 August 2019): 16-38.

${ }^{34}$ Imām Abdul Fattāḥ, Riḥlah Fì Fikr Zaki Naguib Mahmūd (Kairo: al-Majlis al-A'la li atsTsaqafah, 2001), 17.

${ }^{35}$ Zaki Naguib Mahmoud, Qiyām Min At-Turāts (Kairo: Dār Asy-Syurūq, 1984), 283, 382. 
of which concerned three (3) issues, namely:

a. Culture

According to Zaki, the Egyptians actually have three major assets to advance and excel; first, they are the Egyptians; second, they are Arabs; third, they are Muslims. ${ }^{36}$ All this capital should be able to make Egypt a developed and superior nation. However, the fact that happened showed the opposite. The Egyptians who were once strong are now weak. In the past, the Egyptians led and excelled. Now they are helpless and increasingly left behind.

In the course of history, one of the keys to the success of the Egyptians, Arabs, and Muslims in the past was self-confidence. According to Zaki, this selfconfidence is currently missing from them. Thus, efforts to build self-confidence in the hearts of Egyptians and Arabs (Muslims) are non-negotiable.

In addition, the self-confidence that is starting to disappear among the people is also getting worse with their perspective in changing the world's life. It is not uncommon to find people who still rely on mystical-spiritualist methods to find solutions to the problems of social life they face. This, according to Zaki, was never exemplified by the Muslim predecessors in building their civilization.

b. Education

According to Zaki, education is the most important factor in realizing the progress of a nation. Education is not only an institution that transfers knowledge to students and fills their brains with scientific knowledge but also trains students to think productively. This condition was not directly proportional to the reality of the world of education that was developing at that time, where the orientation of education was more focused on the development of cognitive aspects and ignored social values. Even the learning design developed also relies more on the memorization method than the reasoning method. The most obvious impact of this educational model was the loss of critical thinking skills and the weak creativity possessed by students.

In addition, the failure of education was also influenced by the lack of attention to the development of the natural sciences. All the energy of society, especially education providers, is devoted to religious sciences. Natural science seems to be a marginalized scientific discipline. The perspective of Muslims, which is more oriented to the happiness of the hereafter than the life of the world, is considered the main factor in the marginalization of the natural sciences. From the perspective of educational goals, this is of course contradictory because the main purpose of the educational process is to create balance in a student, including balance in life orientation. This principle of balance will later be able to create superior individuals and have creative and innovative thinking.

Specifically, Zaki also criticized the education model in higher education. According to him, universities have lost their main mission as guardians of science and art, which upholds scientific studies, experiments, and scientific research. The literature in various libraries seems to have lost its academic value. Even this must be exacerbated by teachers who do not have adequate competence.

According to Zaki, ideally, the world of education should be able to answer the problems and challenges of the modern world which is all materialist and secular. For this reason, education in the Islamic world must be able to offer many

${ }^{36}$ Sa'̄̄d Murād, Zaki Najīb Maḥmūd Arā' Wa Afkār (Zaqaziq: Ein li ad-Dirāsat wa al-Buhūts alIjtima'iyah, 1997), 139-42; Zaki Naguib Mahmoud, Fi Muftariq At-Ṭurūq (Kairo: Dar Asy-Syurūq, 1993), 193. 
solutions, not only for science itself but also for improving the quality of people's lives in the modern era. ${ }^{37}$

c. Family Law

Besides cultural and educational issues, Zaki also criticized many family law issues in the Islamic world. The position of women Vis a Vis men and polygamy are two issues that get strong criticism from Zaki. According to Zaki, Islam really respects women. Marrying a woman means binding her in a sacred bond based on love and mutual respect for one another. This ideal does not seem to always correspond to reality in the real world. In Egypt, for example, many Muslim practices show a lack of respect and respect for women. Regarding this, Zaki said:

"In our world, marriage is not based on love. The husband does not choose the wife, on the contrary, the wife does not choose the husband. The important thing is that there is a man and a woman in the house. When a husband has got a certain job, the problem is considered solved. Besides, when the wife is a descendant of A and her face is beautiful, it is considered that the problem has also been solved. Marriage is not the union of two hearts and minds". 38

In terms of divorce and polygamy, Zaki also did a harsh criticism. He stated, "I hated divorce, and anti-polygamy". According to Zaki, divorce is one of the causes of the unfavorable atmosphere in the household. Divorce also has a serious impact on the growth and development of the abandoned child. It also was delivered by Rahimi et al, that children who grow up and flourish in conditions of broken families have the potential to grow in a bad family setting and they will continue the damage that they received from parents who divorced when they marry later. ${ }^{39}$

Similar to divorce, Zaki also criticized the behavior of Muslims in polygamy. In Egypt, polygamy is permitted under the Law of Personal Status 1929 and was amended in $1985 .{ }^{40}$ According to him, most of the polygamy that occurs in society is far from the ideal message of the Shari'a. Polygamy, which is supposed to be a problem solver, is often a part of the problem. Instead of being a solution, polygamy actually creates a lot of disharmony in married life. Many cases of polygamy that lead to divorce. Likewise, many practices of polygamy are far from shari'a values.

\section{Zaki's Political Ideas}

Although he did not enter into the realm of practical politics by becoming a politician, Zaki was not absent in giving some views on the political issues that developed during his time. Among Zaki's political ideas are:

${ }^{37}$ Alaf Gaufar, Tantangan Islam, trans. Anas Mahyudin (Bandung: Pustaka, 1982), 210.

${ }^{38}$ Murād, Zaki Naj̄̄b Mahmmūd Arā' Wa Afkār, 53.

${ }^{39}$ Shahram Abdol Rahimi, All Reza Shakarbigi, and Ghoobad Naderi, 'Phenomena Effects of Divorce on Families and Society', Journal of Basic and Applied Scientific Research 2, no. 5 (2012): 4640-41; Also read. Paul R. Amato and Denise Previti, 'People's Reasons for Divorcing: Gender, Social Class, the Life Course, and Adjustment', Journal of Family Issues, 16 November 2016, https://doi.org/10.1177/0192513X03254507.

${ }^{40}$ Amira Mashhour, 'Islamic Law and Gender Equality: Could There Be a Common Ground?: A Study of Divorce and Polygamy in Sharia Law and Contemporary Legislation in Tunisia and Egypt', Human Rights Quarterly 27, no. 2 (2005): 580. 
a. The Concept of Political Science

According to Zaki, political science is the science of how to change social reality. The social reality in question is the various entities that manifest, not an ideal concept or utopian imagination about how a social institution and system is imagined. This reality speaks of "you", "he" and "them". It could have transformed into the figure of Ismail, Ibrahim, Zaenab, or Fatimah. It can also manifest in Egypt, America, China, or others. This reality should not be static and stagnant but must be able to be dynamic with conditions that require it to always develop and change. The presence of political science is needed in order to develop a pattern and system so that the changes that occur lead to a better and more advanced situation. In this case, political science must be able to bring about changes from people who were previously stupid to smart, from a difficult life to be easier, and from a lazy life attitude to being diligent and enthusiastic. ${ }^{41}$

Zaki's perspective on politics seemed different from the views of several other figures. Harold Lasswell, for example, defines politics as "who gets what, when and how." While Hans Morgenthau understands politics as "a struggle for power". Schattchneider calls politics "the art and science of government", and Easton defines politics as "patterns" - patterns of power, rules or authority". ${ }^{2}$

In the discourse on politics, Zaki seemed to still understand politics as something ideal to be used as a tool of social change, not merely a tool to gain power. While other thinkers understand politics more in terms of a more practical level where the question of power and how to obtain it are the main keywords in defining politics.

b. Nationalism

The discourse on the relation between Islam and nationalism is an interesting topic to discuss. This is due to two important factors. First, the concept of nationalism is not explicitly found in Islamic doctrine and is considered contrary to the concept of the ummah. The difference between the two is that the ummah is a concept of citizenship that is based on religious values, while nationalism is based on nationality and geographical boundaries. Second, on the contrary, groups who understand that practically all countries, including countries with a majority Muslim population, adopt nationalism and nation-states simultaneously. ${ }^{43}$

For him, "Nationalism" is the fundamental spirit of Zaki Najib Mahmud's struggle in all fields that he was involved in. For Zaki, Nationalism (Egypt) is a necessity of civilization for the Egyptian people. Since the Pharaoh dynasty, the Egyptians have inherited an almost complete civilization, including law, religion, art, agriculture, war skills, and so on. ${ }^{44}$

In addition, Egypt is part of the Arab nation that has a language with a massive contribution to the development of culture in the world. According to Zaki, Arabic in a cultural context is not just speaking skills, but it is more than that. It is a medium for thinking, a medium for expressing ideas and feelings, and

\footnotetext{
${ }^{41}$ Zaki Naguib Mahmoud, Mujtama' Jadīd Aw al-Karīsah (Kairo: Dār asy-Syurūq, 1991), 81.

42 James A. Caporaso and Davis P. Levine, Teori-Teori Ekonomi Politik, trans. Suraji (Yogyakarta: Pustaka Pelajar, 2008), 4-5.

43 Robitul Firdaus, "Nasionalisme "Jalan Tengah": Mengurai Potensi Benturan Ideologi Nasionalisme dan Sentimen Ummah Di Era Nation State', Akademika: Jurnal Pemikiran Islam (online) 23, no. 2 (19 September 2018): 313-14.

${ }^{44}$ Mahmoud, Fi Muftariq At-Ṭrūq, 357.
} 
a medium for establishing relationships with other cultures. The Arabs, according to Zaki, are a group of people who speak Arabic, live in the same blood culture, and share the same views. ${ }^{45}$

The two basic things above are the reasons why Egyptians should be proud of their nation and homeland. This pride for the nation and homeland, according to Zaki, is starting to erode. Therefore, Zaki often reminded the Egyptian people not to forget the history that they are a nation with a great civilization and have a language (Arabic) that is able to form a noble culture.

c. Politics and power

Zaki's idealistic political understanding was a critique of the political notion, which was always focused on power struggles since this typically leads to tyranny and oppression of the people, particularly those who have opposing political views. In this case, Zaki had a special concern regarding the oppression carried out by the rulers. According to him, a tyrannical ruler is likened to someone who is poor in spirit. He looked inside himself, it was empty soulless. Then he tried to see and seek out by forcing people who have heart and soul to submit to him.

The source of injustice is the absence of a heart in a person which causes him/her to become barren, isolated, and lack self-confidence. Harassment is a disease that afflicts a person, then destroys his soul, and destroys those around him. $^{46}$

The picture of the tyranny of the rulers appears very clearly in the historical traces of the leaders of the Eastern world. According to Zaki, this condition is very worrying. Therefore, he mentioned:

"This is already in our blood. Ruler in the tyrant east. The leaders there are tyrannical. Parents are tyrants too. Rich people are like that too. All tyrants, dictators. Their souls flow the blood of dictatorship and injustice". ${ }^{47}$

What Zaki said did not seem too exaggerated when faced with the fact how Husni Mubarak (Egypt), Mammar Gadafi (Libya), and Saddam Husein (Iraq) run their wheels of power. They are often referred to by some as a representation of the tyranny and dictatorship of modern-day Arab leaders.

One form of tyranny, according to Zaki, is when a leader makes his voice and decisions the only thing that must be obeyed. No other voice and decree may violate the voice and decree of the ruler. ${ }^{48}$ There is no room for compromise and dialogue, especially with parties with opposing political directions.

\section{d. Tyranny of the Majority}

The phenomenon of the existence of majority and minority groups is a natural thing and, at the same time, it is a social necessity in the context of sociopolitical relations in many countries (nations). These two categories will always exist to accompany the dynamics of the social, political, and cultural life of a nation. The issue of agreeing or disagreeing, coalition or opposition, as well as certain stratifications in the socio-political realm, is allegedly the most dominant

\footnotetext{
${ }^{45}$ Mahmoud, 361.

${ }^{46}$ Zaki Naguib Mahmoud, Al-Komīdiyā al-Arḍiyyah (Kairo: Dār Asy-Syurūq, 1989), 81.

${ }^{47}$ Mahmoud, 82.

${ }^{48}$ Zaki Naguib Mahmoud, Tajdīd Al-Fikr al- 'Arabiy (Kairo: Dār Asy-Syurūq, 1986), 29.
} 
giving rise to the majority and minority categories.

According to Zaky, to present a positive value relationship between the majority and minority, it requires reliable and qualified management from the power holders. The incompetence of the authorities in managing this may actually lead to a human tragedy in the form of the tyranny of the majority against the minority. In its simple form, the tyranny of the majority can take the form of hegemony or the dominance of opinions from groups that are considered the majority and ignore the opinions of groups that are considered minorities. Although it seems simple, this type of tyranny, according to Zaky, is more dangerous than the dictatorship of a king. In relation to this, Zaky stated:

"I will mention a new god in human life. That is when the majority has forced everyone to submit and obey all its ideas and decisions". 49

e. Freedom

One of the most important issues in the history of human thought is the issue of freedom (freedom). All thinkers agree that humans are empowered beings who basically have the freedom to will, act, and determine their own destiny. Along the way, this freedom sometimes becomes very expensive and hard to find. It can be either in the form of human freedom related to their relationship with God, or freedom in the social sphere.

In classical Islamic theology, the issue of freedom has become a classic debate among the existing schools of theology. Two thoughts that stand out and contradict each other in this regard are the Qadariyyah and the Jabbariyyah. Some thoughts try to offer an intermediate argument between the two, namely the thought of Ahlu Sunnah wa al-Jamaah (sunni). ${ }^{50}$ Both Qadariyyah and Jabariyyah are deeply involved in the eternal debate about whether humans have freedom or God actually has absolute will. ${ }^{51}$

Zaki's attention to the issue of freedom seems to be narrated in a line of thought that describes a model of movement from old thinking patterns to new ones. In the old way of thinking, for example, Zaki tried to explore the Mu'tazilah idea which defines freedom as something that is always related to freedom of will which leads to the human ability to create actions. According to Zaki, this kind of understanding must be recycled by presenting concepts that are more contemporary and down to earth, especially in terms of choosing word diction. ${ }^{52}$ For this reason, Zaki emphasized that freedom is freedom from all ties and shackles that castrate creativity. Freedom is the freedom to work and innovate. ${ }^{53}$ This kind of freedom, according to Zaki, is still not fully realized in various countries.

${ }^{49}$ Zaki Naguib Mahmoud, Ru’yah Islāmiyah (Kairo: Dār Asy-Syurūq, 1968), 31.

${ }^{50}$ Mohammad Yunus Masrukhin, 'The Will and the Presence of Human Being in Abu al-Hasan alAsh'ari's Thought: Explaining the Relation between Human and God in Kalam Discourse', Al-Jami'ah: Journal of Islamic Studies 59, no. 1 (30 June 2021): 221-22, https://doi.org/10.14421/ajis.2021.591.221254.

${ }^{51}$ Classical books on kalam are filled with discussions of this theme, as well as how the different schools of Islamic kalam compare. One of the books that has become the main reference is the one written by Syahrastani. Asy- Syahrastani, Al-Milal Wa an-Nihal (Beirut: Dār Al-kutub Al 'Ilmiyah, 1990); Harun Nasution, Teologi Islam Aliran-Aliran Sejarah Analisa Perbandingan (Jakarta: UI Press, 1986).

${ }^{52}$ Hasan Hanafi, Min Al-Aqīdah Ilā Ats-Tsaurah (Kairo: Maktabah Madbuli, n.d.).

${ }_{53}$ Murād, Zaki Najīb Maḥmūd Arā' Wa Afkār, 153-54; Zaki Naguib Mahmoud, Hașād As-Sinin (Kairo: Dār asy-Syurūq, 1991), 91. 
The concept of freedom offered by Zaki seems to have a unique value when compared to other thinkers. Tahir Azhari, for example, mentioned that freedom includes five (5) things which are at the same time a basic right for humans, namely: (1) freedom of religion; (2) freedom of thought and expression; (3) freedom to own property (freedom in the economy); (4) freedom to try and choose work; and (5) freedom to choose the place of residence. The five freedoms are not only recognized but also must be protected in the state (law). ${ }^{54}$

According to Ali Abdul Wahid Wafi, the principles of freedom must really be applied in all aspects of life. This is what makes Islam ever reach the peak of glory that is difficult to find comparisons in other religions or nations. ${ }^{55}$ According to Wafi, freedom in the Islamic tradition can be grouped into 4 categories, namely:

1) Civil Liberties, namely the status that makes a person free to carry out various transactions, bear burdens, and responsibilities, own immovable and movable property, and manage his property.

2) Freedom of Religion, namely the freedom to choose religion and belief. In this case, Islam teaches about the principle of tolerance in respecting religious choices and differences.

3) Freedom of Thought and Expression, what is meant by freedom of thought and opinion is that everyone has the right to think independently about everything around him and phenomena that cross his mind and hold on to the results of his thoughts (ideas) and express them in various ways.

4) Political Freedom, what is meant by political freedom is that the people are the source of all power and decisions. In this case, the people must be given at least two rights, namely the right to choose a leader and the right to monitor or correct the performance of their leader, either directly or through their representatives. ${ }^{56}$

\section{Conclusion}

Zaki Naguib Mahmud's journey of thought had gone through 3 unique phases in his intellectual-academic career, namely the simple religious phase (before leaving for Europe), the pure intellectual phase (while living in Europe), and the enlightened religious phase (returning from Europe and living in Egypt). These had led him to become an important figure in the history of Islamic thought in the Islamic world, especially in the Arab world.

Zaki did not only devote their thoughts to one issue alone, but he also viewed almost all socio-religious issues. In the political realm, Zaki also contributed a lot of thought, more precisely criticism to the political situation that developed at the time.

Starting with a critical study of the social conditions of the Arab Muslim community (Egypt), Zaki then offered several political concepts that were not only oriented to power, but also to a more ideal vision of strengthening nationalism and upholding freedom. Power in the political context must not ignore the principles of humanity as well as respect for various existing social entities, especially minority groups. Politics that establish a tyranny of power, according to Zaki, is a tragedy of civilization

\footnotetext{
${ }^{54}$ Mahmoud, Hașād As-Sinin, 97.

55 Ali Abdul Wahid Wafi, Kebebasan Dalam Islam, trans. Said Agil Husain al Munawar (Semarang: Dina Utama, 1997.), 3-5.

${ }^{56}$ Wafi, 62.
} 


\section{E. Acknowledgments}

The author would like to thank the institution where he served, namely Universitas Islam Negeri Prof. K.H. Saifuddin Zuhri Purwokerto which supported this research.

\section{F. Author Contributions Statement}

All authors contributed equally to this work. SS wrote the original draft, theory, and methodology. DH completed the draft, review, and enrich the analysis. AR translated and edited the draft[.]

\section{REFERENCES}

Abdi, Supriyanto. 'Understanding Religion-State Relations in Muslim Societies: Beyond Essentialist and Secular-Liberal Narratives'. Indonesian Journal of Interdisciplinary Islamic Studies (IJIIS) 1, no. 1 (8 February 2018): 27-48. https://doi.org/10.20885/ijiis.vol1.iss1.art2

Alī Abd, Al-Rāziq. Al-Islām Wa Ușūl al-Hukm. Translated by Mamduh Haqq. Beirut, 1966.

Ali, Muhamad. 'Nationalism and Islam: Perspective of Egyptian and Syrian Muslim Intellectuals'. Indonesian Journal of Islam and Muslim Societies 4, no. 1 (1 June 2014): 51-79. https://doi.org/10.18326/ijims.v4i1.51-79

Amato, Paul R., and Denise Previti. 'People's Reasons for Divorcing: Gender, Social Class, the Life Course, and Adjustment'. Journal of Family Issues, 16 November 2016. https://doi.org/10.1177/0192513X03254507

As-Sanhuri, Abd ar-Razzāq. Fiqh Al-Khilāfah Wa Tațawwuruhā. Kairo: al-Haiah al'Ammah lil Kitab, 1993.

Badarussyamsi, Badarussyamsi. 'Pemikiran Ali Abdurraziq Tentang Hubungan Islam Dan Negara'. TAJDID: Jurnal Ilmu Ushuluddin 14, no. 2 (2 November 2015): 325-42. https://doi.org/10.30631/tjd.v14i2.5.

Caporaso, James A., and Davis P. Levine. Teori-Teori Ekonomi Politik. Translated by Suraji. Yogyakarta: Pustaka Pelajar, 2008.

El Khachab, Chihab. 'A Brief History of the Future of Culture in Egypt'. Journal of the African Literature Association 15, no. 3 (2 September 2021): 364-78. https://doi.org/10.1080/21674736.2021.1935065.

Engineer, Asghar Ali. 'Theological Creativity of Abul Kalam Azad'. Indian Literature 31, no. 4 (126) (1988): 17-29.

Farābī, Al-. Arā' Ahl Madīnah al-Faḍilah. Beirut: Dar wa Maktabah al-Hilal, 1995.

Fattāḥ, Imām Abdul. Rihlah F̄̄ Fikr Zaki Naguib Mahmūd. Kairo: al-Majlis al-A'la li ats-Tsaqafah, 2001.

Firdaus, Robitul. 'Nasionalisme "Jalan Tengah": Mengurai Potensi Benturan Ideologi Nasionalisme dan Sentimen Ummah Di Era Nation State'. Akademika : Jurnal Pemikiran Islam (online) 23, no. 2 (19 September 2018): 313-38.

Gaufar, Alaf. Tantangan Islam. Translated by Anas Mahyudin. Bandung: Pustaka, 1982.

Goetsch, Charles C. 'The Future of Legal Formalism'. The American Journal of Legal History 24, no. 3 (1980): 221-56. https://doi.org/10.2307/844666.

Hanafi, Hasan. Min Al-Aqīdah Ilā Ats-Tsaurah. Kairo: Maktabah Madbuli, n.d. 
Hidayat, Asep Ramdan. 'Islam dan Negara Pemikiran Ali Abd. Ar-Raziq'. MIMBAR : Jurnal Sosial dan Pembangunan 19, no. 2 (8 June 2003): 159-68. https://doi.org/10.29313/mimbar.v19i2.100.

Irham, Irham, and Zakaria Husin Lubis. 'The Dynamics of Contemporary Islamic Thinking and the Role of Education: Islamic Fundamentalism, Opponents, and Hybrid Thought'. Al-Tahrir: Jurnal Pemikiran Islam 21, no. 1 (18 May 2021): 105-33.

Jamshed, Qazi Mohd. 'Ideological Influences on Abul Kalam Azad'. Proceedings of the Indian History Congress 71 (2010): 662-76.

Juliansyahzen, Muhammad Iqbal. 'Rekonstruksi Nalar Arab Kontemporer Muhammad 'Abed Al-Jabiri'. Indonesian Journal of Islamic Law 1, no. 2 (26 August 2019): $16-38$.

Karsh, Efraim, and Inari Karsh. 'Reflections on Arab Nationalism'. Middle Eastern Studies 32, no. 4 (1 October 1996): 367-92. https://doi.org/10.1080/00263209608701135.

Kazemzadeh, Masoud. 'Teaching the Politics of Islamic Fundamentalism'. PS: Political Science and Politics 31, no. 1 (1998): 52-59. https://doi.org/10.2307/420434.

Klein, Menachem. 'Egypt's Revolutionary Publishing Culture, 1952-62'. Middle Eastern Studies 39, no. 2 (1 April 2003): 149-78. https://doi.org/10.1080/714004504.

Liu, Zhongmin, and Meng Shu. 'Nationalist Thoughts and Islam in the Late Ottoman Empire'. Asian Journal of Middle Eastern and Islamic Studies 11, no. 2 (1 June 2017): 14-26. https://doi.org/10.1080/25765949.2017.12023298.

Maarif, Ahmad Syafii. 'Muhammad Iqbal Dan Suara Kemanusiaan Dari Timur'. In Rekonstruksi Pemikiran Agama Dalam Islam, translated by Ali Audah. Yogyakarta: Jalasutra, 2008.

Mahmoud, Zaki Naguib. Al-Komīdiyā al-Arḍiyyah. Kairo: Dār Asy-Syurūq, 1989.

Mahmoud, Zaki Naguib. Fi Muftariq At-Ṭurūq. Kairo: Dar Asy-Syurūq, 1993.

Mahmoud, Zaki Naguib. Haṣād As-Sinin. Kairo: Dār asy-Syurūq, 1991.

Mahmoud, Zaki Naguib. Mujtama'Jadīd Aw al-Karīsah. Kairo: Dār asy-Syurūq, 1991.

Mahmoud, Zaki Naguib. Qiyām Min At-Turāts. Kairo: Dār Asy-Syurūq, 1984.

Mahmoud, Zaki Naguib. Ru'yah Islāmiyah. Kairo: Dār Asy-Syurūq, 1968.

Mahmoud, Zaki Naguib. Tajdìd Al-Fikr al-'Arabiy. Kairo: Dār Asy-Syurūq, 1986.

Mashhour, Amira. 'Islamic Law and Gender Equality: Could There Be a Common Ground?: A Study of Divorce and Polygamy in Sharia Law and Contemporary Legislation in Tunisia and Egypt'. Human Rights Quarterly 27, no. 2 (2005): 562-96.

Masrukhin, Mohammad Yunus. 'The Will and the Presence of Human Being in Abu alHasan al-Ash'ari's Thought: Explaining the Relation between Human and God in Kalam Discourse'. Al-Jami'ah: Journal of Islamic Studies 59, no. 1 (30 June 2021): 221-54. https://doi.org/10.14421/ajis.2021.591.221-254.

Matesan, Ioana E. 'The Impact of the Arab Spring on Islamist Strategies'. Journal of Strategic Security 5, no. 2 (2012): 27-46. http://dx.doi.org/10.5038/19440472.5.2.2.

Mather, Yassamine. 'The Fall of the Ottoman Empire and Current Conflict in the Middle East'. Critique 42, no. 3 (3 July 2014): 471-85. https://doi.org/10.1080/03017605.2014.972151.

Munhanif, Ali, and M. Dahlan. 'Lineages of Islamic Extremism in Egypt: Ikhwan alMuslimun, State Violence and the Origins of Radical Politics'. Al-Jami'ah: 
Journal of Islamic Studies 56, no. 2 (8 September 2018): 421-60. https://doi.org/10.14421/ajis.2018.562.421-460.

Murād, Sa'īd. Zaki Naj̄̄b Maḥmūd Arā' Wa Afkār. Zaqaziq: Ein li ad-Dirāsat wa alBuhūts al-Ijtima'iyah, 1997.

Muslim Contributions to World Civilization. International Institute of Islamic Thought, 2005. https://doi.org/10.2307/j.ctvk8w275.

Mustofa, Imam, Enizar Enizar, Mukhtar Hadi, and Dedi Irwansyah. 'Reading Types of Islamic Fundamentalism in Lampung Province (A Study on Doctrine and Movement of Islamism at Lampung University)'. QIJIS (Qudus International Journal of Islamic Studies) 7, no. 2 (30 December 2019): 267-300. https://doi.org/10.21043/qijis.v7i2.5719.

Nabhany, Taqiyudin an-. Pembentukan Partai Politik Islam. Translated by Zakaria Labib. 2nd ed. Jakarta: Penerbit HTI Press, 2007.

Nafia, Ilman, and Septi Gumiandari. 'The Root of Islamic Fundamentalism in The Political Thoughts of Al-Maududi and Sayyid Qutb: A Historical Study'. Jurnal Tamaddun: Jurnal Sejarah Dan Kebudayaan Islam 7, no. 2 (1 December 2019). https://doi.org/10.24235/tamaddun.v7i2.5497.

Nasr, Sayyed Hossein. Traditional Islam in Modem World. London: Oxford University, 1983.

Nasution, Harun. Teologi Islam Aliran-Aliran Sejarah Analisa Perbandingan. Jakarta: UI Press, 1986.

Nelli, Jumni. 'Pemikiran Politik Ali Abd Al-Raziq'. An-Nida' 39, no. 1 (5 February 2014): 76-90. https://doi.org/10.24014/an-nida.v39i1.866.

Osman, Mohamed Nawab Mohamed. 'Hizbut Tahrir Malaysia: The Emergence of a New Transnational Islamist Movement in Malaysia'. Al-Jami'ah: Journal of Islamic Studies 47, no. 1 (26 June 2009): 91-110. https://doi.org/10.14421/ajis.2009.471.91-110.

Qodir, Zuly, Hasse Jubba, Mega Hidayati, Irwan Abdullah, and Ahmad Sunawari Long. 'A Progressive Islamic Movement and Its Response to the Issues of the Ummah'. Indonesian Journal of Islam and Muslim Societies 10, no. 2 (21 December 2020): 323-52. https://doi.org/10.18326/ijims.v10i2.323-352.

Rahimi, Shahram Abdol, All Reza Shakarbigi, and Ghoobad Naderi. 'Phenomena Effects of Divorce on Families and Society'. Journal of Basic and Applied Scientific Research 2, no. 5 (2012): 4639-47.

Rijal, Syamsul. 'Indoctrinating Muslim Youths: Seeking Certainty Through AnNabhanism'. Al-Jami'ah: Journal of Islamic Studies 49, no. 2 (24 December 2011): 253-80. https://doi.org/10.14421/ajis.2011.492.253-280.

Rofiq, Muhamad. 'Arab Political Reasoning: Muhammad Abid Al-Jabiri's Contribution for Understanding Crisis of Politics in the Arab World'. Indonesian Journal of Islam and Muslim Societies 7, no. 1 (1 June 2017): 55-76. https://doi.org/10.18326/ijims.v7i1.55-76.

Saeed, Abdullah. Interpreting the Qur'ān: Towards a Contemporary Approach. Abingdon [England]; New York: Routledge, 2006.

Sukardi, Imam. Pemikiran Politik Al-Farabi (Diskursus Kepemimpinan Negara). Disertasi. Jakarta: SPs UIN Syarif Hidayatullah, 2008.

Syadzali, Munawwir. Islam Dan Tata Negara. Jakarta: UI Press, 1990.

Syahrastani, Asy-. Al-Milal Wa an-Nihal. Beirut: Dār Al-kutub Al ’Ilmiyah, 1990. 
Syamsuddin, Sirajuddin. 'Pemikiran Politik: Aspek Yang Terlupakan Dalam Sistem Pemikiran Islam'. In Refleksi Pembaharuan Pemikiran Islam. Jakarta: LSAF, 1989.

Umar, Ubaid. Al-Syaikh al-Ra '̄̄s Ibn Sināa. Riyadh: Dār al-Syawwāf li al-Ṭibā'ah wa alNasyr, 1989.

Vikør, Knut S. 'Islamic Law in the Modern World: States, Laws, and Constitutions'. In Islamic Studies in the Twenty-First Century, edited by Léon Buskens and Annemarie van Sandwijk, 205-22. Transformations and Continuities. Amsterdam University Press, 2016. https://doi.org/10.2307/j.ctt1zxsk97.13.

Wafi, Ali Abdul Wahid. Kebebasan Dalam Islam. Translated by Said Agil Husain al Munawar. Semarang: Dina Utama, 1997

Warburg, Gabriel R. 'Islam and Politics in Egypt: 1952-80'. Middle Eastern Studies 18, no. 2 (1 April 1982): 131-57. https://doi.org/10.1080/00263208208700502.

Yusuf, Burhanuddin. 'Ali Abdul Raziq Kajian Teologis Atas Pemikirannya'. AqidahTa: Jurnal Ilmu Aqidah 3, no. 1 (2017): 1-12. https://doi.org/10.24252/aqidahta.v3i1.3274.

Zuhdi, M. Nurdin. 'Kritik Terhadap Penafsiran Al-Qur'an Hizbut Tahrir Indonesia'. Akademika : Jurnal Pemikiran Islam (Online) 18, no. 2 (22 October 2013): 20934. 
